\title{
The Peer Review Process of the Global Forum on Transparency and Exchange of Information for Tax Purposes
}

\author{
A Critical Assessment on Authority and Legitimacy
}

Leo E.C. Neve*

\begin{abstract}
The Global Forum on transparency and exchange of information for tax purposes has undertaken peer reviews on the implementation of the global standard of exchange of information on request, both from the perspective of formalities available and from the perspective of actual implementation. In the review reports Global Forum advises jurisdictions on required amendments of regulations and practices. With these advices, the Global Forum exercises regulatory authority. The article assesses the legitimacy of the exercise of such authority by the Global Forum and concludes that the exercise of such authority is not legitimate for the reason that the rule of law is abused by preventing jurisdictions to adhere to due process rules.
\end{abstract}

Keywords: Global Forum on Transparency and Exchange of Information, exercise of regulatory authority, due process requirements, peer review reports, legitimacy

\section{Introduction}

In her essay on the validity of global standards in tax law Ana Paula Dourado takes the position that the lack of respect for the rule of law disqualifies the OECD standard for exchange of information on request ('EOIR Standard' or 'the Standard') as a global standard. ${ }^{1}$ Her main argument is that the current standard jeopardises taxpayers' fundamental rights as acknowledged in ruleof-law states. Her starting point is the coexistence of plural legal orders within domestic boundaries. In my own words: various groups in society (constituencies) may differ about what is right with respect to tax evasion, with the views of ruling authorities, for example, differing from those of blue-collar labourers. ${ }^{2}$ The glob- al legal discourse, however, is moving in the direction of finding solutions for global problems - such as tax evasion through the use of tax havens and secrecy jurisdictions - at a global level, with the trend being towards setting global standards. That discourse is itself a product of global identity and solidarity, along with a sense of global fairness and unfairness, and global human and fundamental rights. According to Dourado, the awareness of phenomena such as tax evasion and avoidance by certain groups of taxpayers, the consequences of banking and tax secrecy and tax havens for each country individually, the importance of exchanging information on tax matters, the right to a fair hearing in tax litigation, information duties and the principle of nemo tenetur se ipsum accusarem are all examples of global problems demanding global solutions and global tax standards. In the author's opinion, uniform standards can provide uniform solutions in those areas where pluralism is not to be favoured.

The concept of the validity of law adopted by Dourado - from Habermas' Faktizität ${ }^{3}$ - is law that is a product of genuine argumentative interaction among representatives of different legalities. This validity of law as a product of an argumentative interaction is more difficult to achieve, however, if the rules are drafted by supranational legalities, as in the case of the exchange of information envisaged by the OECD. ${ }^{4}$ On this basis, Dourado comes to her thesis that legal instruments and action taken by individual tax administrations have to respect taxpayers' rights. For Dourado, validity of law requires

a communicative discourse (with separation of powers and different legal realities represented), safeguards of fundamental taxpayers' rights and related limitations on the activity of administration and courts, a clear prohibition of the use of illicitly obtained data and the absence of corruption, among other things. ${ }^{5}$
3. J. Habermas, Faktizität und Geltung, Beiträge zur Diskurstheorie des Rechts und des demokratischen Rechtsstaats (Frankfurt-am-Main, 1992).

4. Dourado, above n. 1, at 3 .

5. Ibid., at 9 . 
None of these criteria, however, is a condition for becoming a member of the Global Forum on Transparency and Exchange of Information ('Global Transparency Forum'), and nor is compliance with these criteria subject to peer review. Ana Dourado therefore questions the democratic legitimacy of the rules established by the OECD and the Global Transparency Forum.

The specific provision in tax treaties on the exchange of information between tax authorities has been in the Model of Tax Conventions ever since this was first drafted by the League of Nations in 1923. However, the provision has undergone major changes since 1998, when the OECD published its report on harmful tax competition, ${ }^{6}$ focusing on transparency and the exchange of information with a view to combating tax evasion through the use of tax havens and secrecy jurisdictions. As a result of tax haven jurisdictions' strong opposition to the - in their view - one-sided opinion of the OECD, it was decided that a more inclusive organisation under the auspices of the OECD would be established. This organisation became the Global Forum on Taxation ('Global Tax Forum'), ' a multilateral framework in which participating countries combine efforts to work towards a level playing field in the areas of transparency and the exchange of information in tax matters. ${ }^{8}$ The Forum started work in 2000 and initially included OECD countries and the six countries politically committed to improving transparency and establishing an effective exchange of information in civil and criminal tax matters. Its first initiative was to develop a Model Agreement on Exchange of Information on Tax Matters (TIEA). ${ }^{9}$ Historically, countries were not obliged to provide information if their domestic legislation prohibited the exchange of confidential information. However, this recognition of domestic sovereignty stood in the way of a global solution for tax evasion through the use of banks and other financial institutions in secrecy jurisdictions. Under the TIEA, therefore, jurisdictions were obliged to restrict domestic secrecy laws that could prevent the exchange of information relating to foreign residents. The provisions of this model were subsequently incorporated into the 2005 OECD Model Tax Convention (MTC) and also found their way into the 2010 UN Model Tax Convention and

6. OECD Report: 'Harmful Tax Competition, an Emerging Global Issue', 1998. The report addresses harmful tax practices in the form of tax havens and harmful preferential tax regimes in OECD member countries and non-member countries and their dependencies, with a focus on geographically mobile activities such as financial and other service activities. It also defines the factors to be used to identify harmful tax practices and goes on to make 19 wide-ranging recommendations to counteract such practices.

7. The Global Forum on Taxation was restructured and renamed in 2009 by decision of the Council of the OECD establishing the Global Forum on Transparency and Exchange of Information ('Global Transparency Forum'). Decision adopted on 17 September 2009 C(2009)122/Final.

8. A different group of countries is involved in the Global Forum's work on tax treaties and transfer pricing.

9. See Tax Co-operation - Towards a Level Playing Field, 2006 Assessment by the Global Forum on Taxation, OECD 2006. the 2010 Protocol to the Multilateral Convention. ${ }^{10}$ The TIEA model has also been widely used to negotiate and conclude tax information exchange agreements, where the objective is 'the creation of an environment in which all significant financial centres meet the high standards of transparency and effective exchange of information on both civil and criminal taxation matters' ${ }^{11}$ Central to the global level playing field between OECD and nonOECD members is the pursuit of 'fairness', meaning that the high levels of transparency are accepted not only by the financial centres of the world, but also by the OECD countries themselves. ${ }^{12}$ This purpose, in turn, gave rise to the idea of a review of countries' legal and administrative frameworks in the areas of transparency and exchange of information. The review was undertaken in the form of a standard questionnaire developed by the Global Tax Forum and which sought information on countries' legal and administrative frameworks for exchanging information, for obtaining information held by banks and other financial institutions and for ensuring the availability of ownership and accounting information and the accessibility of ownership, identity and accounting information. ${ }^{13}$ The OECD publication '2006 Assessment by the Global Forum on Taxation' reflects the outcome of the first factual review of these frameworks.

In this way the Global Tax Forum has exercised considerable influence on the shaping of the universal rule and states' commitment to mutual administrative assistance in tax matters. However, the rule does not, in itself, create a strong compliance pull. Although most countries will certainly benefit from improved mutual assistance, others will bear the cost in the form of a higher administrative burden on their tax administrations and on those who have the information in their possession, as well as lower income from tax revenue and fees. It was consequently decided to seek to create a 'level playing field', without any 'free-riders'. As a result, OECD Member States such as Switzerland, Luxembourg and Austria have since been forced to relinquish their bank secrecy, while this obligation had already been imposed on UK overseas territories.

By March 2009, almost all jurisdictions had agreed to implement the new Standard, with heavy pressure and the threat of countermeasures being necessary to get some of them to agree. The Global Tax Forum had been tasked by the G20 with verifying the implementation of the information exchange provisions among tax authorities and supplying progress reports on the implementation of and practice under the new Standard. After being restructured in September 2009 to strengthen the implementation of the standards for transparency and exchange of information, the renamed Global Transparency Forum launched an ambitious peer

10. Council of Europe/OECD 1988 Convention on Mutual Administrative Assistance in Tax Matters as Amended by 2010 Protocol.

11. Global Forum meeting, Berlin, June 2004, report.

12. OECD Global Forum meeting, Berlin, June 2004, report para. 6: Definition of a Global Level Playing Field.

13. OECD, above n. 9, para. 4 . 
review process of national legislation in the realm of tax transparency and, having been instructed to oversee the compliance and peer review process, has since developed 'Terms of Reference' (see Sections 2 and 3 below). The first round of peer review reports was completed in November 2016, with the result that the Global Transparency Forum has now rated 99 of the 116 jurisdictions that participated in the second phase of reviews. In order to get a positive rating, some countries have been forced to amend their legislation on timely and effective processes of exchange. ${ }^{14}$ The especially critical procedures in this respect relate to notification of the intention to exchange information, the possibility of reviewing decisions to exchange, the length of court proceedings, and the right to be heard with disclosure of documents. In the process, therefore, of moving towards positive compliance ratings, interested persons (specifically the information owner and the subject of the investigation) have lost valuable legal protection rights. Examples of countries in which this applies include the Netherlands, which introduced a bill on 25 September 2013 to amend the International Assistance (Levying of Taxes) Act. ${ }^{15}$ This bill proposed abolishing the notification procedure and thereby restricting the opportunities for review by a court. In his explanatory note to the proposed amendment, the State Secretary argued that the peer review report recommended abolishing this notification procedure and also that the new EU Directive on Administrative Cooperation (DAC 1) ${ }^{16}$ did not recognise this procedure. ${ }^{17}$ The amendment also meant that the person would no longer be able to ask for a judicial review of the decision to grant the information request. ${ }^{18}$ Since 1 January 2014, therefore, the possibility of a judicial review has no longer been available. ${ }^{19}$

Just over a year later, on 25 November 2014, Luxembourg introduced legislation to amend its Act of 31 March 2010. ${ }^{20}$ Under Article 6(1) of the amended legislation, no legal remedy is available against a request for exchange of information or against a decision ordering the production of information. The only remedy available is against the penalty imposed for not complying with the order. ${ }^{21}$ The Luxembourg government, too,

14. Terms of Reference, para. 8: Exchange of information for tax purposes is effective when reliable information, foreseeably relevant to the tax requirements of a requesting jurisdiction is available, or can be made available, in a timely manner and there are legal mechanisms that enable the information to be obtained and exchanged.

15. Wet Internationale bijstand bij de heffing van belastingen

16. Directive 2011/16/EU.

17. Parliamentary Papers II 2013/14, 33753, 3, at 10-11

18. Ibid., at 34-35.

19. That statement was repeated during the parliamentary process of approving the bill on the implementation of the automatic exchange of tax rulings, Parliamentary Papers I 2016/17, 34527, B, at 2

20. Mémorial, Recueil de législation, Appl. No. 214/27, 27 November 2014, at 4170 .

21. This issue is now decided in CJEU 16-5-2017, Berlioz Investment Fund S.A., C-682/15, ECLI:EU:C:2017:373, where the Cour d'appel has requested a preliminary ruling from the CJEU. See also Cour d'appel Luxembourg, 36893C argued that the Global Transparency Forum required Luxembourg to make these changes. ${ }^{22}$

In its Cahier de droit fiscal international of 2015, the International Fiscal Association (IFA) ${ }^{23}$ also identified Austria, Liechtenstein, Portugal and Switzerland as jurisdictions under pressure from the Global Transparency Forum to remove their existing procedures for notifying taxpayers and their ability to challenge crossborder exchange of information (EOI). ${ }^{24}$

On the basis of its Terms of Reference, the Global Transparency Forum criticised the above countries, especially on elements dealing with the rights and obligations of taxpayers and third persons. The Forum's authority and the strength of its recommendations are such that these countries were forced to amend their laws. In that respect, the Global Transparency Forum is both a rule-maker and rule-adjudicator.

The changes in the laws of these jurisdictions imposed by the Global Transparency Forum were criticised by Baker and Pistone, who stated in their general report on the 2015 IFA conference (subject B) that ' $\mathrm{We}$ would take the opportunity to note that we find it wholly inappropriate that existing and apparently effective protections for taxpayers' rights should be removed through pressure placed on the states concerned.' In other words, the authors write that, in seeking to balance the rights of the persons involved against states' interests in an effective exchange of information procedure, the rights of taxpayers and third persons have been violated. Baker and Pistone write from the presumption that the administrative decision to exchange information is an infringement of a fundamental individual right and should be subject to judicial review, which cannot be denied or reduced without serious reasons. This presumption is based on the fact that information exchanged may significantly and adversely affect a person's interests. ${ }^{25}$

The basic question that this contribution seeks to answer concerns the Global Transparency Forum's legitimacy and authority to impose the above amendments of domestic legislation on member jurisdictions and third countries. Essentially this involves reflecting on how an international standard, through the authority of the Global Transparency Forum, impacts on domestic constitutional rights of the individual (i.e. the right to be heard and the right to have access to a court) and on how a standard developed by a network of state agents is able to prevail over the domestic legislation of a jurisdiction. My analysis will examine the remarks of Ana Dourado, as referred to above, from the perspective

22. See Chambre députés, projet loi Doc. parl. 6680; sess. extra ord. 2013-2014 et sess. ord. 2014-2015 and Peer review report on Luxembourg, phase 2, at 103 and 112 .

23. For the IFA, see <https://www.ifa.nl/Pages/default.aspx>. The IFA is a non-governmental and non-sectoral international organization that offers a forum for experts from different sectors of society to exchange opinions on topics of international taxation with regard for each other's background and responsibilities.

24. See P. Baker and P. Pistone, General Report IFA 2015, 'The Practical Protection of Taxpayers' Fundamental Rights', at 51.

25. See A.-G. Kokott in Sabou C-276/12, ECLI:EU:C:2013:370, para. 51. 
of the taxpayer or third-party information holder subject to the exchange of information.

The contribution is structured as follows: In order to come to the core of the answer, I will first look at the history and authority of the Global Transparency Forum and its structure, composition and mandate. The EOIR Standard is reflected in the Terms of Reference formulated for the peer review procedures, which aim to monitor and enforce the implementation of the Standard. Section 2 assesses the legal status of the Terms of Reference. Section 3 qualifies the exchange of information procedure as an act of state, while also explaining how the rights of defence are fundamental rights of persons involved in the process of exchange of information, and exploring the legitimacy framework and the structure in which authority is exercised in the global governance of tax. Section 4 examines this exercise of global authority as a form of the global administration of tax, with discussion of whether principles derived from global administrative law should apply. The contribution closes with conclusions in Section 5.

\section{Global Transparency Forum}

\subsection{Introduction}

In the introduction I stated that the Global Transparency Forum is jeopardising the procedural rights of taxpayers by requiring the relevant state to provide the requested information without delay and to remove impediments to the effectiveness of the procedure. This raises questions about the Global Transparency Forum's authority. In this section I will first look into the institutional aspects of the Global Transparency Forum, its membership and mandate. The Forum has developed the EOIR Standard, which is set out in the Terms of Reference and consists of various components and elements. Adherence to the Terms of Reference is subject to peer review, whereby a jurisdiction is assessed in two phases and ultimately receives a qualification. The EOIR Standard has to be enforced between jurisdictions, while rights of citizens are also to be respected.

\subsection{Origins}

The Global Transparency Forum was created in the early 2000s as part of the OECD's work on addressing the risks that tax havens pose to tax compliance. ${ }^{26}$ Following the OECD's 1998 report on harmful tax competition, OECD member countries and jurisdictions that had agreed to implement the Standard for Transparency and Exchange of Information participated in creating the Global Forum. In 2006 this Forum published a report ('Tax Co-operation - Towards a level playing field, 2006 Assessment') that referred to the concept of the 'level playing field' as follows: 'The level playing field is fundamentally about fairness to which all parties

26. The Global Transparency Forum is the continuation of its predecessor, the Global Forum on Taxation. in the Global Forum are committed. ${ }^{27}$ That fairness is meant to exist between OECD member states and nonmember jurisdictions. The point here is that some important OECD Member States (i.e. Switzerland, Luxembourg and Austria) were still refusing to implement provisions for exchanging financial and ownership information held by banks and other financial institutions. In late 2008, however, newspaper publications on tax evasion by private persons forced governments to move forward with the transparency issue. This culminated in March 2009 in the 'surrender' of the above states and in the elimination of banking secrecy for tax purposes. As a result, much of the level playing field was achieved, and the G20, supplementing the OECD, had taken on a leading role in global tax governance.

\subsection{Structure and Composition}

The Global Transparency Forum is formally a programme under Part II of the OECD budget and has a self-standing, dedicated secretariat based at the OECD's offices in Paris. The OECD itself is an entity under international law that was established by treaty in 1961 . It currently has 35 members and an annual budget of $€ 350$ million. Exceptionally, nationals of non-OECD member countries can join the Forum's secretariat. The Global Transparency Forum now has 139 members, ${ }^{28}$ with the conditions for membership being the commitments: (1) to implement the international standard on transparency and exchange of information on request (as reflected in the Terms of Reference ${ }^{29}$ developed by the Global Transparency Forum); (2) to participate and contribute to the peer review process; and (3) to contribute to the budget. All members have an equal voice in the decision-making process and all decisions are taken by consensus. All member jurisdictions have committed themselves to the EOIR Standard, while 90 of the 139 members have also committed themselves to the automatic exchange of information ('AEOI Standard'). The Global Transparency Forum is composed of government representatives and is therefore, in institutional terms, a 'public network', with legal personality derived as part of the OECD and without direct representation. ${ }^{30}$ The Global Transparency Forum is consequently not a formal supranational authority, and any rules it proposes are not automatically legally binding. The work of the Global Transparency Forum is guided and prepared by a steering group.

27. OECD, above n. 9 , at 46 .

28. At 6 March 2017, see <https://www.oecd.org/tax/transparency/aboutthe-global-forum/members/>

29. Terms of Reference to Monitor and Review Progress towards Transparency and Exchange of Information for Tax Purposes, OECD, CTPA 2010.

30. For the foundations of 'networks' and their impact, see A.-M. Slaughter and D.T. Zaring, 'Networking Goes International: An Update', Washington \& Lee Legal Studies Paper No. 2007-12, Annual Review of Law \& Social Science, Vol. 2, December 2006. Available at SSRN: <http:// ssrn.com/abstract=960484> 


\subsection{Mandate}

Under the Global Transparency Forum's original mandate, which expired on 31 December 2012, the Forum is charged with promoting effective implementation of the international standards of transparency and exchange of information for tax purposes. As set out in the Resolution establishing the Global Forum, its mission is to ensure a rapid and effective global implementation of the standards of transparency and exchange of information for tax purposes through in-depth monitoring and peer review. The original mandate was extended to 31 December 2015, when a new mandate was agreed by the Council of the OECD. The Global Forum has since obtained a new mandate from G20 that includes a mandate to create a mechanism to monitor and review implementation of the AEOI Standard, and to work to ensure that developing countries can benefit from this. This mandate expires on 31 December 2020.

\subsection{EOIR Standard}

As stated in the introduction, the provision for the exchange of information on request is not new. Historically, it was intended for the benefit of applying double tax agreements ('small' assistance clause). In recent years, however, it has also become a tool for enforcing domestic tax laws of the requesting state, without any requirement for a tax interest of the requested state. It has also extended to cooperation with respect to criminal tax investigations ('broad' assistance clause). Since 2003, the clause has sought to restrict domestic provisions preventing the exchange of information. States can no longer excuse themselves by claiming not to have the proper domestic legislation in place to provide information or having legislation that prevents an exchange. The EOIR Standard stipulates that states should have legislation in place that allows for the exchange of the requested information to the widest extent possible and that the receiving authority is bound to protect the confidentiality of the information and must use it for tax purposes only. ${ }^{31}$ This 'speciality clause', however, has come under pressure as tax information can also be relevant for suppressing other financial crimes. The 'tax purposes only' label may be lifted with the agreement of the providing authority, but without requiring any form of approval by the subject. The EOIR Standard is currently moving towards becoming an Automatic EOI, while the new AEOI Standard is being reviewed by the Global Forum. ${ }^{32}$

31. These obligations are contained in Article 26(1) OECD MC, with Article 26(3) providing exemptions from the obligations and Article 26(5) restricting the exemptions provided for in Article 26(3).

32. See more on EOIR Standard: Klaus Vogel on Double Taxation Conventions, 4th edition by Reimer and Rust (ed.), Kluwer Law International (2015); X. Oberson, International Exchange of Information in Tax Matters (Edward Elger, 2015); R. Danon, D. Gutmann, X. Oberson \& P. Pistone (eds.), Modèle de Convention fiscal OCDE concernant le revenu et la fortune, Commentaire (Helbing Lichtenhahn, Editions Francis Lefebvre 2013); K. Vogel and M. Lehner (eds.), DBA Doppelbesteuerungsabkommen, Kommentar, 6. Auflage (Verlag C.H. Beck, München, 2015).

\subsection{Terms of Reference}

\subsubsection{Sources}

The Terms of Reference developed by the Global Tax Forum derive from three different sources. The primary source is the 2002 Model Agreement on Exchange of Information on Tax Matters and its Commentary (TIEA-MA), which includes the EOIR Standard as developed by the OECD. In addition to this primary source, the peer review group uses secondary sources in the form of reports developed by OECD and the Global Transparency Forum, and which provide context for understanding and interpreting standards. One of the important documents in this respect is the standard for the maintenance of reliable accounting records devised by the Joint Ad Hoc Group on Accounts in 2005. ${ }^{33}$

\subsubsection{Components and Elements}

The Terms of Reference for assessing adherence to the EOIR Standard contain three basic components, broken down into ten essential elements. These are:

a. Information that must be available in the requested state on:

1. Ownership and identity information;

2. Reliable accounting records; and

3. Banking information for all accountholders;

b. Information that must be accessible in the requested state:

1. The requested state should have the power to obtain and provide information from any person within their territorial jurisdiction who is in possession or control of such information;

2. The rights and safeguards (e.g. notification, appeal rights) that apply to persons in the requested jurisdiction should be compatible with effective exchange of information;

c. Both states must have a mechanism for exchange of information (legal basis) so that:

1. Exchange of information mechanisms provide for effective exchange of information;

2. The jurisdictions' network of information exchange mechanisms cover all relevant partners;

3. The jurisdictions' mechanisms for exchange of information have adequate provisions to ensure the confidentiality of information received;

4. The exchange of information mechanisms respect the rights and safeguards of taxpayers and third parties; and

5. The jurisdiction provides information under its network of agreements in a timely manner.

\subsection{Monitoring and Enforcement}

These Terms of Reference convert a contracting party's commitment to adhere to the EOIR Standard into an obligation under international law to provide administrative assistance to a requesting state and to implement

33. Terms of Reference to Monitor and Review Progress towards Transparency and Exchange of Information for Tax Purposes, OECD, CTPA 2010 . 
all such laws that are necessary in order to comply with the terms. By accepting membership of the Global Transparency Forum, jurisdictions commit to the Terms of Reference and become subject to the peer review process. Jurisdictions' commitments are based on that membership and are independent of any treaty obligation. In that respect, the Forum resembles a multilateral convention, but with a stronger enforcement mechanism and without any need for parliamentary approval of the international commitments.

Although the EOIR Standard is not a legal instrument, the Global Forum monitors both formal and practical legislative adherence in an attempt to ensure that the Standard is implemented with no or little deviation. In the European Union, adherence is enforced by the Directive on Administrative Cooperation (DAC 1). ${ }^{34} \mathrm{~A}$ number of countries and jurisdictions are stalling with the implementation of the Standard and not fully applying it in practice. This has had consequences: some EU Member States have compiled their own 'blacklists', which were published by the Commission on 17 June 2015 ('The pan-EU list of third-country non-cooperative jurisdictions'). ${ }^{35}$ The Top 30 of non-cooperative jurisdictions consists of countries featuring on at least ten Member States' own blacklists. This publication provoked a strong reaction from the secretariats of the OECD and Global Forum, ${ }^{36}$ which explained that the EU Commission had incorporated the Global Forum's Terms of Reference into its principles of good governance in tax matters. At the same time, however, both secretariats complained that EU Member States had not followed the assessments of the Global Forum, while also claiming that only the Global Forum can assess countries' adherence to the exchange of information. It is unclear as to what extent this reaction from the OECD and Global Forum secretariats has influenced individual EU Member States to decide to follow the assessment of the Global Forum rather than to go it alone.

Other than ranking a jurisdiction's compliance, the Global Forum has no mechanism to enforce a jurisdiction to effectively engage in exchange of information. The pan-EU list of third-country non-cooperative jurisdictions, to be prepared by the Code of Conduct Group ${ }^{37}$ allows the European Commission to consider 'measures' against non-compliant third states. Although the list will not be a legally binding instrument, it will have political force. At the end of 2017 the list will be added to the Code of Conduct by the ECOFIN Council. ${ }^{38}$ The latter can then instruct the Commission to draft a directive to make the list a legally binding

Council Directive 2011/16/EU of 15 February 2011 on administrative cooperation in the field of taxation and repealing Directive 77/799/EEC, OJ L 64, 11 March 2011, at 1-12.

35. Press release memo/15/5175 dd 15 June 2015.

36. Letter of 19 June 2015 to Global Forum members.

37. Code of Conduct group, established by ECOFIN Council meeting, 1 December 1997, <http://ec.europa.eu/taxation_customs/sites/taxation/ files/resources/documents/coc_en.pdf>

38. Council of Economics and Finance Ministers (ECOFIN) of the European Union. instrument. As EU Member States have to transpose EU directives into their national legislation, any Member State failing to implement a directive can be challenged in an infringement procedure at the EU Court of Justice (CJEU). ${ }^{39}$

\subsection{Rights of Citizens}

The Terms of Reference used as the benchmark for the peer review process refer only marginally to rights of citizens. Only B.2 (rights and safeguards of persons in the requested jurisdiction) has a bearing on basic rights of citizens. However, the benchmark is formulated to the effect that rights (notification and appeal rights) should be restricted insofar as they could hinder an effective and expedient exchange of information. In the OECD Commentary on OECD MTC, para 19.11, reference is made to judicial or administrative procedures for access to protected information. The Commentary makes clear that such procedures 'should not be so burdensome [LN: for the requested state] and time-consuming as to act as an impediment to access to banking information'. It should also be noted that B.2 refers only to persons in their capacity as information holders in the requested jurisdiction and does not as such provide rights to taxpayers. We should additionally bear in mind that Article 26 of the OECD MTC, when implemented, provides only for rights and obligations of the contracting states. The addressee of any request made is the requested state. However, rights of other persons (such as taxpayers and third-party information holders) can also be affected by the exchange of information.

An additional issue is that the reference in C.4 to rights and safeguards of taxpayers and third parties refers mainly to the obligation of the requesting state to respect the confidentiality of the information received and its obligation to use the received information only for the purposes for which it was requested (purpose restriction). This reference is not intended to give rights to the taxpayer or the third party. Similarly, it does not define the rights that should be respected, except for the positive obligation on the requesting state to protect the confidentiality of the received information as an extension of the confidentiality obligation imposed on the requested state. We can thus conclude that citizens in this process cannot derive rights from the provisions in Article 26 OECD MTC.

\subsection{Peer Review}

The EOIR Standard is reflected in the Terms of Reference, with compliance to be ensured through an indepth peer review process. All Global Forum members, as well as jurisdictions identified by the Forum as relevant to its work, will undergo peer reviews of their legal and regulatory frameworks for transparency and exchange of information in tax matters and for implementing the standards in practice. As mentioned above, the EOIR Standard has been broken down into three main categories, comprising ten essential elements.

39. Article 258 TFEU 
These make up the Terms of Reference for assessing compliance and implementation of the EOIR Standard.

The Global Forum has decided that the peer review process should consist of two phases. The first phase will assess a jurisdiction's legal and regulatory frameworks for exchanging information (i.e. the theoretical part), while the second phase will assess the jurisdiction's effective implementation of the EOIR Standard in practice (i.e. the practical part). The peer review group's evaluation reports have to be adopted by all the Global Forum members, while members are also expected to act on any recommendations in the review and to report back to the Global Forum on actions taken.

Once a jurisdiction has undertaken to implement the international EOIR Standard, it obviously has to proceed to do so and then to exchange all information 'foreseeably [of] relevance' for the enforcement of taxes. This should be defined 'to the widest possible extent' without entering the territory of 'speculative requests', being requests that have 'no apparent nexus to an open inquiry or investigation'. ${ }^{40}$ Foreseeably relevant information includes accounting information. The Joint $\mathrm{Ad}$ Hoc Group on Accounts (JAHGA) has qualified 'accounting information' in its report and has determined that it applies to 'Relevant Entities and Arrangements', which are broadly defined to include: (i) a company, foundation, Anstalt and any similar structure; (ii) a partnership or other body of persons; (iii) a trust or similar arrangement; (iv) a collective investment fund or scheme; and (v) any person holding assets in a fiduciary capacity (e.g. an executor in the case of an estate). ${ }^{41}$ The JAHGA report therefore more or less imposes a requirement on jurisdictions hosting entities and arrangements to be able to make accessible and reliable accounting records of those entities and arrangements available. Many jurisdictions (tax havens) have consequently introduced a legal obligation to maintain an administration. The Global Forum conducts peer reviews of its member jurisdictions' ability to cooperate with other tax administrations in accordance with the internationally agreed standard.

The peer review group will qualify the level of adherence in phase 1 (the theoretical and substantive phase) in one of three possible ways: 'The element is in place', 'The element is in place, but certain aspects of the legal implementation of the element need improvement' or 'The element is not in place'. The classifications in phase 2 (the practical phase) are 'compliant', 'largely compliant', 'partially compliant' or 'non-compliant', while the classifications in the overall assessment are as in phase 2 .

40. It is questionable whether these terms have autonomous meaning. As case law in various countries shows, courts in these jurisdictions try to give a domestic meaning to the terms, but this plurality of meanings is not accepted by the Global Forum.

41. JAHGA report 'Enabling Effective Exchange of Information: Availability Standard and Reliability Standard' in Tax Co-operation - Towards A Level Playing Field, OECD 2006, <www.oecd.org/ctp/harmful/ 42179473.pdf>.
The Global Forum has now completed 235 peer reviews and assigned compliance ratings to 113 jurisdictions that have undergone phase 2 reviews. A total of 22 jurisdictions have been rated 'compliant', 77 'largely compliant', 12 'partially compliant' and 5 'non-compliant'. ${ }^{42}$ Jurisdictions without sufficient elements in place cannot move on to phase 2 and so are at risk of countermeasures.

\subsection{Section Conclusion}

It can be concluded from this section that, from the perspective of the OECD and Global Forum, the exchange of information is a process operating between competent authorities. This is because the Terms of Reference refer only to rights and obligations of contracting parties and make no provision for the subject of the investigation (i.e. the taxpayer under investigation) or the thirdparty information holder. However, the subject and the information holder have legal rights, too. The exchange of information concerns the exchange of the taxpayer's personal or other information, or information on the taxpayer originating from the third party. The EOIR Standard requires a speedy process, without delays attributable to interference by the subject. The Global Forum's focus is clearly not on seeking a balance between, on the one hand, administrative effectiveness and, on the other hand, the recognition of basic procedural rights of persons involved, including the judicial review of acts of state. And this different focus, in turn, has an impact on the rights of the subject, as we shall see in the next section.

\section{Rights of Defence}

\subsection{Introduction}

As mentioned in the introduction to the contribution, the perspective for assessing the legitimacy of the peer review process is that of the person subject to an investigation in the requesting state, with specific regard for the fairness of the procedure. Under the rule of law, the rights of defence are some of the most important rights available to a subject seeking to protect himself against a governmental decision that severely impacts on the subject's basic civil rights. These rights relate to fair treatment and an equitable procedure. The position of the subject in the EOIR process (in either capacity) must be recognised as it is the subject's civil rights that are at stake. The subject basically has three distinct rights: due process fairness, confidentiality of personal data, and data protection. Recognising the procedural rights of the persons involved in the EOI procedure will often lead to a delay in the process and will in any event have an impact on the effectiveness of the administrative procedure. The Global Forum consequently has a clear bias towards effectiveness over fairness, based on the pre-

42. See: <www.oecd.org/tax/transparency/exchange-of-information-onrequest/ratings/>. These five jurisdictions include three jurisdictions that have not undergone a phase 2 review. 
sumption that the subject can bring his case before the court in the requesting state. However, this bias leaves the affected third party without recourse to adjudication. The following subsections touch upon various aspects of the rights of defence available to taxpayers and third parties in the requested state.

\subsection{Fundamental Rights of the Taxpayer}

The protection of taxpayers' rights has recently received much attention. ${ }^{43}$ Minimum standards (good practice) and best practices are circulating among authorities and interested parties. Citizens have basic rights that should not be neglected in any transnational exchange of information, whether under an EU Directive or a bilateral or multilateral tax convention. The rights that have been agreed internationally are the right to be informed, the right to be able to participate in the decision-making process, the right to be heard in the event of a direct and immediate impact on the person, the right of access to judicial review by an independent court, and the right to privacy and data protection. In a pluralistic legal environment, however, these rights are not uniform. If the rules are to be applied uniformly, it would consequently be helpful for the instrument providing the legal basis for the EOI process also to contain basic protection rights for the persons involved, such as a provision to the effect that when an exchange of information takes place under the EU Directive on Administrative Cooperation (DAC) ${ }^{44}$ the affected person has all the rights and freedoms granted by the EU Charter of Fundamental Rights (ECFR), ${ }^{45}$ including the freedom of the right of respect for private and family life (Article 7), protection of personal data (Article 8), the right to property (Article 17), the right to good administration (Article 41), the right to access to documents (Article 42), the right to an effective remedy and to a fair trial (Article 47), and the presumption of innocence and the right of defence (Article 48). Although these rights and freedoms are not absolute, any limitation on exercising them must be provided for by law and must respect the essence of those rights and freedoms. Subject to the principle of proportionality, limitations may be made only if they are necessary and genuinely meet the objectives of general interest recognised by the Union or the need to protect the rights and freedoms of others (Article 52, para. 1). Rights corresponding with the rights granted under the European Convention on Human Rights shall have the same meaning and scope as those rights, although Union law can provide greater protection (Article 52, para. 3). Recognised fundamental rights

43. See Baker and Pistone, above n. 24; G. Kofler, M. Poiares Maduro \& P. Pistone (eds.), Human Rights and Taxation in Europe and the World, a publication of the Group for Research on European and International Taxation (<www.greit-tax.eu>). See also 'CFE: Towards Greater Fairness in Taxation: A Model Taxpayer Charter' at <www.taxpayercharter. com> and P. Baker and P. Pistone, 'BEPS Action 16: The Taxpayers' Right to an Effective Legal Remedy Under European Law in Cross-Border Situations', 5-6 EC Tax Review 335 (2016).

44. Directive 2011/16/EU.

45. EU Charter of Fundamental Rights, (OJ) 2010 C83/02 and again in (OJ) 2012 C326/391. derived from the constitutional traditions common to EU Member States shall be interpreted in harmony with those traditions (Article 52, para. 4).

Good tax administration takes into account a certain protection of taxpayers' confidential information. Most countries recognise the confidentiality of information given by taxpayers and consequently impose strict secrecy obligations on their administration.

The requesting state has to decide which taxpayer rights may be involved and how these rights can be best protected. In the competent authority letter, as the starting point for the investigation, the requesting state will provide information on the taxable subject and the relevance of the requested information for the assessment procedure. The Commentary on the OECD MTC takes the position that the competent authority letter is subject to a duty of confidentiality. ${ }^{46}$ The Commentary authorises the disclosure of a minimum of information (but not disclosure of the letter itself) if such is necessary to enable the requested state to obtain or provide the information to the requesting state, without frustrating the efforts of the requesting state. In this, the Commentary seems to take precedence over domestic due process rules as, under the latter rules, the competent authority letter is not generally privacy-protected information, given that it is relevant for reviewing the legality of the investigation order and so normally needs to be disclosed. Only in exceptional circumstances, when disclosure would threaten the success of the investigation, may non-disclosure be appropriate. Having received the results of the request, the requesting state then has to protect the personal rights of third parties in the requested state. The personal rights of legal entities are specifically emphasised in this respect. Legal entities do not enjoy a high level of protection as they lack the dignity of a moral person. However, although the privacy article in the ECFR (Article 7) applies only to natural persons, Article 8 of the European Convention on Human Rights (ECHR) extends the protection of home and correspondence to legal persons.

The requested state, which is obliged to perform the request, has to decide whether to use all its discretionary powers to obtain the information and whether it needs to consider the safeguards offered by the requesting state to the taxpayer in respect of the information supplied. This is because the obligation to perform the request is subject to certain restrictions. ${ }^{47}$ These restrictions must be taken seriously as national sovereignty may conflict with the principle of mutual trust and good faith, as applied in international law. ${ }^{48}$ Where the law does not provide straightforward procedural protection, the general principle of equality of arms serves as an

46. Para. 11, Commentary.

47. Article 26(3) OECD MTC limits the main rule by releasing the requested state from the obligation to disclose information in certain circumstances (e.g. a sovereignty clause, reciprocity clause, privilege against selfincrimination, information that cannot be obtained in normal administrative procedure, and if disclosure would conflict with public order).

48. Article 26 Vienna Convention on the Law of Treaties, and A. Aust, Modern Treaty Law and Practice, 2nd ed. (2007), 179. 
arbitrator in the adjudication of rights: in other words, there should always be a balance between taxpayers' obligations to disclose non-public information and taxpayers' rights to retain a level of dignity, free from state interference. The global tax governance institutions, however, do not seem to recognise any right of the individual in the requested state to be free from interference by that state for the purposes of assisting in the enforcement of the requesting state's tax laws. Indeed, the Global Transparency Forum has specifically ordered states to restrict domestic due process rules that assist subjects in the requested state to defend their basic rights.

\subsection{Confidentiality and Data Protection}

The Terms of Reference recognise the importance of confidentiality for the subject in two elements. On the one hand, they protect the confidentiality of information collected and exchanged and impose the same confidentiality norms for received information on the requesting state as the latter provides for its own information under its own laws (i.e. the principle of equal treatment). ${ }^{49} \mathrm{On}$ the other hand, the requirement that only information foreseeably relevant for the requesting state can be exchanged implies a proportionality test. In this way, the interests of third-party informers (no obligation to provide more than is relevant) and taxpayers (purpose restriction) are protected. However, the Standard also undermines the rights of third parties and taxpayers by extending the restricted purpose to 'other use' if such other use is permitted under the laws of the requesting state and the requested state agrees to such use. Neither the taxpayer nor the third party has any say in this other use. The OECD standard of protection then applying is the standard of the requesting state, even if the requested state itself has a higher standard of confidentiality. This is a strange provision because it may reduce the protection afforded by the requested state to the taxpayer or the third-party informant.

In the $\mathrm{EU}$, this will lead to a conflict between the rights afforded to taxpayers and the obligations of the requested state under the OECD MTC or similar arrangements. Within the EU legal framework, the protection in the receiving country should be at least equal to the protection afforded by the state seeking to exchange the information. If protection is not on an equal footing, the exchange should be restricted. In the past, existing differences between EU Member States prohibited the processing of personal data. The Data Protection Directive $(95 / 46 / \mathrm{EC})$ (DPD) consequently sought to equalise the differences by imposing equivalent protection in all Member States. ${ }^{50}$ Under Article 25(1) DPD, transfer to third countries (outside the EU) may take place only if the third country in question ensures an adequate level of protection of the personal information. In the famous case of Schrems v. Data Protection Commissioner, the CJEU ruled that the legal framework of protection

49. Article 26(2) OECD MTC.

50. DPD, preamble 7 and 8. against abuse in the United States was generally not sufficient to allow information to be transferred to and held in the United States by Facebook. ${ }^{51}$

Contrary to its general obligations under international agreements (the United States has undertaken to exchange information on deposit interest with 86 jurisdictions), the United States has only qualified 18 jurisdictions with which it will exchange information on non-alien deposit interest. ${ }^{52}$ Having reviewed its domestic confidentiality provisions, the United States has only partly confirmed the reciprocity promised under the FATCA IGA agreements. For the vast majority of countries, it is correct to state that more of their taxpayers' assets are held in or through the United States than vice versa. Some governments are denied reciprocity by the United States because these countries use their tax administration, and the information received from it, against citizens or foreign competitors, while some tax administrators selectively use tax information against political rivals. ${ }^{53}$ Some governments simply lack the capacity to protect tax information because of a lack of resources, lack of protection against cybercriminals, or a lack of will, while others do not consider tax information confidential or pass it on to other government departments. William Byrnes has therefore concluded that the Protocol amending the Multilateral Convention on Mutual Assistance in Tax Matters (allowing the automatic exchange of information) may potentially lead to substantially more identity theft, crime, industrial espionage, financial fraud and suppression of political opponents and religious or ethnic minorities by authoritarian and corrupt governments, including Russia, China, Colombia and Nigeria. ${ }^{54}$

On the other hand, the restriction to the effect that the information received is to be used only for tax purposes has been criticised by the Financial Transparency Coalition on the grounds that this prevents prosecution of criminals for financial offences other than strict tax fraud ${ }^{55} \mathrm{~A}$ recent EU Commission initiative for intensified collaboration between anti-money-laundering enforcement officers and tax authorities is another sign of 'creep' in the restricted purpose. ${ }^{56}$ In this way, the fight against tax evasion through transparency and

51. CJEU 6 October 2015, C-362/14 (Schrems v. Data Protection Commissioner), Celex 62014CJ0362.

52. See W. Byrnes, White, Grey and Black Hat Tax Administrations - A proposal for a U.S. Carrot \& Stick Approach, Part I, Kluwer International Blog, 16 August 2016 referring to Rev. Proc. 2012-24, superseded by Rev. Proc. 2014-64 listing as appropriate jurisdictions Australia, Canada, Denmark, Finland, France, Germany, Guernsey, Ireland, Isle of Man, Italy, Jersey, Malta, Mauritius, Mexico, Netherlands, Norway, Spain and the United Kingdom for interest paid after 1 January 2015

53. See, as a general example, ECtHR case Yukos v. Russia, Appl. No. 14902/04.

54. See Byrnes, above n. 52

55. See <https://financialtransparency.org/information-exchange-needs-go -beyond-tax/> (accessed 13 February 2017).

56. See Proposal for a Council Directive amending Directive 2011/16/EU as regards access to anti-money-laundering information by tax authorities, Celex 52016PC0452. Especially targeted here is information on the beneficial owners of intermediary entities and other relevant customer due diligence information, if the authorities are to effectively identify and address tax evasion. 
exchange of information is becoming part of a larger objective: the prevention of illicit flows of funds. ${ }^{57}$

\subsection{Legal Qualification Process of EOIR}

The mutual administrative assistance treaties concluded by states are more than just inter-state agreements as they also create obligations for a state's citizens to cooperate by providing personal protected information to other states for the purposes of enforcement and collecting taxes in those other states. In this way, national laws are put in service of the interests of other states, with the result that one state exercises transnational authority with the permission of the other state. However, while international cooperation has advantages for both the requesting and the requested state, the burdens are not equally shared. Some states more often than not find themselves on the requesting side, while others are on the requested side. This requires differential treatment. ${ }^{58}$

The current view of the CJEU (in Sabou) ${ }^{59}$ and the ECtHR (in Othymia) ${ }^{60}$ is that the exchange of information upon request does not constitute an act giving rise to an obligation to hear the person concerned (taxpayer) either before the investigation takes place or before the results of the investigation are exchanged with the requesting country. The party concerned is not entitled to receive notification prior to the exchange: 'It cannot be a requirement of Article 8 of the Convention [ECHR] that prior notice of lawful tax investigations or exchanges of tax-related information be given to all persons potentially implicated' (Othymia, 44). In most countries, the exchange of information process is seen as mere 'fact gathering' and not as a proper administrative procedure. ${ }^{61}$ This underlines that the protective rights are granted only at the level of the requesting state. Both courts also make a distinction between the 'investigation' stage and the 'contentious' stage. A request for information forms part of the investigation stage: 'is part of the process of collecting information'. ${ }^{62}$ The rights of defence are consequently seen as coming into play only when the process enters the contentious stage, which begins when the taxpayer is sent the proposed adjustment. ${ }^{63}$ In the opinion of the CJEU, respect of the tax-

57. In their statement of 14 April 2016, the five EU Ministers of Finance attending the G20 focused on the fight against tax evasion, aggressive tax planning and money laundering and underlined the common patterns in money laundering, tax evasion and illicit finance.

58. See M. Keen and J. Ligthart, 'Information Sharing and International Taxation: A Primer', 13 International Tax and Public Finance 81-110; Discussion Paper, University of Tilburg, CentER, Discussion Paper No. 2004-117; M. Keen and J. Ligthart, 'Revenue Sharing and Information Exchange under Non-Discriminatory Taxation' (June 2005), CentER Discussion Paper No. 2005-69.

59. Case C-276/12, Sabou. ECLI:EU:C:2013:678. See also L.E.C. Neve, case note on Sabou in AB 2014/37.

60. ECtHR 16 June 2015, Othymia Investments BV, Appl. No. 75292-10. See also T. Barkhuysen and M.L. van Emmerik, case note on Othymia in $A B$ 2017/2, who plead for re-introduction of the notice of intention to exchange.

61. X. Oberson, IFA General Report 2013, 'Exchange of Information and Cross-border Cooperation between Tax Authorities', 54.

62. Case C-276/12, Sabou, ECLI:EU:C:2013:678, rec. 42.

63. Ibid., rec. 39 payer's rights of defence does not require the taxpayer to take part in the request for information or to be heard when inquiries are being carried out or before the requested Member State sends the information to the requesting Member State. ${ }^{64}$ The positions adopted by the CJEU and ECtHR are currently, however, subject to debate.

It is argued that the taxpayer has no right to be informed or to participate in any way in the process of EOI decision-making because this process is part of the administrative/procedural stage of an investigation. At that point, there is no discussion and, therefore, no right to interfere. That approach, however, is flawed, ${ }^{65}$ and the error is evident in Sabou. The actions taken by the requested state to obtain the information from the information holder cannot be reviewed by the adjudicating court in the requesting state for their compatibility with the rights granted under the ECFR or ECHR, given that the sovereignty clause prevents a court in the requesting state from reviewing acts of state of another state. This is a flaw in the international process. However, the domestic court does have procedural autonomy to evaluate evidence obtained in the exchange procedure. ${ }^{66}$

The taxpayer has general rights to privacy and confidentiality at all stages of the process; there is, for example, a prohibition on exchanging a trade, business, industrial, commercial or professional secret or trade process. But how can an infringement of this provision be challenged if there is no access to a court?

The adjudication of conflicts in EOI processes is based on a national procedural (administrative) framework, whereas the exchange in substance is based on international commitments. In this context of European (and global) legal pluralism, one cannot ignore a parallel denationalisation of political, and especially legislative, institutions and the importance of reconnecting legislative and judicial functions across levels of governance. A further question, therefore, is whether such adjudication should take account of the transnational environment in which the exchange takes place and, if so, what effects this will have on national procedures? In national procedures, domestic authorities often have a carve-out for tax procedures. Such procedures often do not follow the general principles of administrative law in that they frequently violate requirements of administrative due process. The basic requirements of administrative due process are threefold: (a) the requirement to carry out a procedure; (b) the right to be heard in that procedure; and (c) the requirement to give reasons for the procedure. $^{67}$

\subsection{Exceptionality}

In searching for 'fairness' in the international exchange procedure we face claims for 'exceptionality' by the

64. Sabou, rec. 44.

65. Baker and Pistone (2015), above n. 24.

66. Case C-437/13, Unitrading, ECLI:EU:C:2014:2318, rec. 35

67. See G. della Cananea, Due Process of Law beyond the State (OUP, 2016). 
competent authorities in these proceedings, either claims for confidentiality of communication, or claims for exceptions to transparency. The Global Transparency Forum's attitude is a good example of the kind of 'exceptionality' that the Forum is requesting for itself by seeking to remove basic rights, such as the right to be notified of an intended EOI, and the right to challenge any decision in this field. The EU Commission is another good example of the kind of 'exceptionality' discussed here. In the preamble to the Directive on Administrative Cooperation 2011/16/EU (DAC 1), the Commission advises Member States to restrict transparency by invoking the general exception of Article 13(1)(e) Data Protection Directive 95/46/EC (DPD). ${ }^{68}$ This means, in my opinion, that the Commission is advising Member States, when implementing the DAC 1, also to include a general exception to the notification requirement foreseen in the DPD. In this way, a right that is given to a subject (the right to access data) is restricted without any procedural compensation. Invoking the priority of national interests, especially in taxation matters, for a general and generic purpose is contrary to the spirit of the DPD. ${ }^{69}$ I recognise that the levying of taxes is of great interest for any state, but that interest cannot be regarded as legitimate justification for denying due process when fundamental civil rights are at stake.

\subsection{Infringements of Civil Rights}

In the past, international cooperation between fiscal authorities of contracting states was often seen as a means of strengthening powers to enforce domestic tax laws, with the exchange of information originally restricted to readily available or accessible information for which no investigation and cooperation of another subject was necessary. Over time, however, the contracting parties' commitments extended to an obligation to cooperate in providing information for which an investigation was necessary. This, however, touches upon the private sphere of the individual, which is when the data and privacy protection provided for in Article 8 $\mathrm{ECHR}^{70}$ and Articles 7 and $8 \mathrm{ECFR}^{71}$ come into play.

The international exchange of information can result in an infringement of third parties' rights through the disclosure, for example, of protected information. However, although an individual has standing under the ECHR if his rights are infringed by a Member State of the Council of Europe, it is difficult to allocate responsibility for the infringement in a transnational investiga-

68. Preamble 27. However, it is appropriate to consider limitations of certain rights and obligations laid down by Directive 95/46/EC in order to safeguard the interests referred to in Article 13(1)(e) of that Directive. Such limitations are necessary and proportionate in view of the potential loss of revenue for Member States and the crucial importance of information covered by this Directive for the effectiveness of the fight against fraud.

69. Article 13, Exemptions and Restrictions (1) reads: '(e) an important economic or financial interest of a Member State or of the European Union, including monetary, budgetary and taxation matters'

70. ECHR, ETS No. 4 and subsequent amendments in ETS 44, 45, 55, 118 , 155, 140 and 194.

71. EU Charter of Fundamental Rights, Celex 12012PTXT, OJ 2012/C $326 / 02$. tion involving cooperation between two or more states. The question arises as to which state is responsible for any violation of the rights of persons protected under the ECHR if a request for assistance is to be complied with. Each state is responsible for actions within its own jurisdiction. But is this appropriate if an act in State A is seen as preparatory for a decision in State B? This is important because qualifying an act of State A as 'preparatory' in nature deprives the subject of the opportunity to take legal action against the act of State $A$, while the subject is also unable to have the act reviewed in State B. ${ }^{72}$

Ensuring the legal protection of citizens is a collective responsibility of all Member States within the Council of Europe. However, ECtHR case law does not accept common responsibility, but instead divides the responsibility of the states. ${ }^{73}$ The fact that the ECtHR found a common responsibility of Denmark and Turkey for the extradition procedure in Sari, but did not find individual neglect meant that the ECtHR was unable to decide on either state's responsibility for not hearing the case within a 'reasonable time'. This may create complications in composite procedures or transnational acts. States have an inter-state obligation to uphold the rule of law. The ECHR comprises a network of mutual and bilateral undertakings, while the objective obligations of states must benefit from collective enforcement. ${ }^{74}$ In my opinion, this means that both states in EOI procedures are responsible for proper performance of the process and for upholding the rule of law. Legitimacy deficits must, therefore, have an impact on the value of the evidence collected in such a process.

Although the use of evidence obtained contrary to the provisions of the ECHR creates responsibilities for states under the ECHR, ${ }^{75}$ this does not mean that evidence obtained in violation of ECHR obligations cannot be used in the adjudication process. ${ }^{76}$ The responsibility of the state is for the reciprocal engagements between contracting states, as well as to protect subjects within its jurisdiction against infringements by other subjects or other states. An example of when the transnational element comes into play can be seen in Ireland v. $U K,{ }^{77}$ when Ireland challenged the UK for not observing the latter's commitments under the ECHR. The Court confirmed that the UK was obliged to observe the ECHR commitments, but did not find a violation of such commitments.

In the EU, the fundamental rights set out in the ECFR protect citizens against infringements by EU institutions and infringements by states in the execution of EU-based regulations (primary or subsidiary), whereas

72. In general, acts of a preparatory nature lack direct effect on subjects' legal position and are, therefore, not justiciable.

73. Sari v. Turkey and Denmark, ECtHR, No. 21889/93.

74. Ireland v. UK, ECtHR, No. 5310/72 para. 239

75. X v. Germany, European Commission of Human Rights (EComHR), No. $1611 / 62$.

76. Especially in procedures where criminal or administrative penalties can be imposed, the ECtHR will consider the 'fairness' of the procedure in total. See P.G. \& J.H. v. United Kingdom, ECtHR No. 44787/98.

77. Ireland v. UK, ECtHR, No. 5310/71. 
ECHR rights impose both positive and negative obligations on states. The CJEU and ECtHR also have different jurisdictions in terms of subjects and subject matters. Such differences can be observed with respect to jurisdiction (Member State action versus EU citizens), the scope of review, and the effect and enforcement of judgements. Article 6 ECHR (right of review by court) deals only with civil and penal claims, rather than with the exercising of public authority in tax matters (unless there are monetary effects). ${ }^{78}$

The EU has changed bilateral and multilateral cooperation, such that its perspective now centres on the interests of Union citizens. We therefore now need principles that are much more oriented towards citizens' fundamental rights than to the economic well-being of the EU Member States. As seen in Van Gend E Loos, the subjects of the new legal order comprise not only the Member States, but also their nationals. ${ }^{79} \mathrm{We}$ have thus moved from a Member State approach to a Union approach, and this influences subjects' procedural rights. But we continue to see a concentration of legal remedies in the requesting state, as reflected in the repeal of the notification procedure and the prohibition of a judicial review in the Dutch International Assistance (Levying of Taxes) Act $[W I B B]$, both of which are contrary to the interests of the subjects.

\subsection{Competence of ECtHR and CJEU as Regards Procedural Tax Law}

Human rights and the protection of these rights have moved from the social platform to the legal platform. We are currently also seeing a constitutionalisation of international law, whereby constitutionally protected civil rights are becoming increasingly important in the application of international law. This constitutional perspective on the body of international law, especially that part of international law dealing with governance, has been gaining importance ever since international law started institutionally regulating the conduct of subjects worldwide. This new perspective on international law can also be seen from a global administrative law perspective, with the intention being to apply the principles of administrative and constitutional law in the field of international law, and the core idea being that the exercising of institutional authority should be restrained and controlled by procedures and processes under law. On the transnational level, individual autonomy should be protected against the authority exercised by the state and its agents in international institutions and networks. This greater focus on human rights in international law applies also in tax law. Daniel Gutmann provides two reasons for this recent trend: ${ }^{80}$ first, the new threats increasingly linked to globalisation and the reinforce-

78. Ferrazzini v. Italy, ECtHR, No. 44759/98.

79. Case, 26/62 Van Gend \& Loos, ECLI:EU:C:1963:1 (direct effect for the individuals).

80. D. Gutmann, 'Taking Human Rights Seriously: Some Introductory Words on Human Rights, Taxation and EU', in G. Kofler, M. Poiares Maduro \& P. Pistone (eds.), Human Rights and Taxation in Europe and the World (IBFD, 2011), ch. 6. ment of tax administrations' powers, and, second, the promotion of social goals such as 'solidarity' or environmental protection, and their effects on tax matters. ${ }^{81}$ Article 1, Protocol 1, of the ECHR balances the rights to tax natural and legal persons against the state's obligation to protect peaceful enjoyment of property. A problematic issue in this respect, however, is the legitimacy of double taxation as no individual state can be held responsible for the existence of double taxation, and taxpayers are reliant on national tax authorities' discretion when it comes to eliminating it in practice. ${ }^{82}$

A similar field of conflict can be seen in the international procedure for the exchange of information. The increased powers legitimately attributed to tax authorities to enforce tax legislation, also in cross-border situations, need to be balanced by a symmetrical acknowledgement of fundamental taxpayer rights. ${ }^{83}$ Gutmann concludes, therefore, that the new powers of tax authorities should be balanced by new rights or by the correct implementation and application of existing rights in tax proceedings. A general reference to the important interests of states in the levying of taxes does not constitute a substitute for neglecting taxpayers' individual rights. Similarly, the reference to the protection of the 'internal market' in Othymia Investments $B V$ does not prohibit the protection of the interests of the individual. ${ }^{84}$

The right to a fair trial is dealt with in Article $6 \mathrm{ECHR}$, while the right of review, extended to everyone, is limited in paragraph 1 to 'the determination of his civil rights and obligations or of any criminal charge against him'. The ECtHR will therefore explore the civil character of tax disputes on its own, irrespective of the nature of the rule or the origin of the competent authority. The criteria used by the Court to recognise a dispute as 'civil' are the existence of a private contract or that the action represents a challenge to private property. With respect to sanctions, the Court will explore the possible penal (or repressive) character of a tax sanction. Tax sanctions in the form of an administrative sanction fall within the scope of Article 6 ECHR on the basis of the general nature of the sanction, its deterrent or repressive nature and its severity. ${ }^{85}$ Conflicts in this field will gain importance as more and more sanctions are based on administrative rather than penal law provisions.

In a mutual legal assistance case between Switzerland as the requested state and Italy as the requesting state, the European Commission on Human Rights was asked to decide on the application of Article 6 ECHR with respect to the subject's rights of defence (including the right to review documents). The Commission decided that the Swiss competent authority's decision related exclusively to the obligations assumed by Switzerland under international agreements. The procedure to oppose this decision (G.A. E A.M. v. Smitzerland) thus

81. Gutmann, above n. 80 , at 108

82. Ibid., at 109.

83. Ibid., at 110 .

84. ECtHR, Othymia Investments, No. 75292/10, para. 41

85. ECtHR 24 February 1994, Bendenoum, Appl. No. 12547/86. 
escapes the application of Article 6 ECHR. ${ }^{86}$ The procedure of mutual administrative assistance for EOI is often seen as similar to a procedure under a mutual legal assistance treaty. Article 6 ECHR will therefore not apply directly (by reference to G.A. E $A . M$. v. Switzerland) to an exchange of information procedure that is not of civil or penal origin. Nevertheless, the due process principles derived from Article 6 ECHR will exercise influence on domestic judicial procedures. For a different view of CJEU on this issue, see the following discussion on the Berlioz case.

\subsection{Berlioz Case - CJEU C-682/15: Important} Issues Decided by CJEU

A case that provides a good overview of the conflicting interests discussed above is that of Berlioz Investment Fund S.A., which has recently been decided by the CJEU. Berlioz, as a third party, is obliged by the laws of Luxembourg to reply to questions of the competent authority. Under the amended legislation, Berlioz cannot object to the request, nor ask for judicial review, while refusing to cooperate attracts a fine of $€ 250,000$. Berlioz refused to reply to certain questions and was fined. It subsequently asked for judicial review of the fine and the underlying order. I will explain the questions, the Attorney-General's advice to the CJEU and the ruling of the CJEU below. The decision was taken on 16 May $2017 .{ }^{87}$

The CJEU has been called on, in a preliminary ruling request, implicitly to decide on the validity of recent amendments of procedural laws in Luxembourg. In the case of Berlioz (C-682/15) the CJEU has been asked to answer six questions relating to a request from France to Luxembourg for exchange of information. The questions 3 and 5 of the Luxembourg Court Administrative were taken together by the CJEU.

Essentially, the ruling of the CJEU was as follows:

i. The first question relates to the application of the ECFR. In order for it to be applicable, the scope of the ECFR must be analysed under article 51. The ECFR is applicable when Union law is implemented. The CJEU concludes that the ECFR is applicable because Member States are required to take every necessary measure to guarantee the effectiveness of the Directive on Administrative Cooperation 2011/16/EU (DAC 1). 'A mechanism for imposing sanctions is most certainly a necessary measure to ensure the effectiveness of the system for the exchange of information established by Directive 2011/16. ${ }^{98}$ In the judgement of Sabou, the CJEU confirmed that the rules on requests for information and on the use of that information form part of the application of EU law. In that case the

86. EComHR 1 December 1986, G.A. \& A.M. v. Switzerland, Appl. No. $11514 / 85$. Its prospective value, however, is limited as the Commission gave an importance level indication of only 3 . As the decision was a non-receivable decision, no appeal to the ECtHR was possible in those days.

87. CJEU, 16-5-2017, Berlioz (C-682/15), ECLI:EU:C:2017:373.

88. Ibid., rec. 41
CJEU considered that 'the questions referred ... concern[ed] the implementation of EU law and [that] the Court [had] jurisdiction to examine the application, in [that] context, of fundamental rights'. ${ }^{89}$ The applicability of the ECFR is thus confirmed.

ii. The second question concerns the right to an effective remedy under Article 47 ECFR. The persons on whom a fine was imposed question the validity of the request for information. The issue here is whether the investigation into the validity of the information request is conditional upon a breach of a specific right or freedom guaranteed in the ECFR. The right to an effective remedy is a general principle of law and the Court can thus review whether the measure is in conformity with the Treaties (TFEU and TEU), with general principles of law and with fundamental rights. Thus if the request for information is made in the context of a procedure that constitutes the implementing of the law of the Union, the Court can review the legality of that request. ${ }^{90}$

iii. The third question, taken together with the fifth question, asks whether the national court has 'unlimited jurisdiction' to assess the proportionality of the penalty and the possibility to examine the legality of the information order on which the penalty is based. The court must have jurisdiction to examine all questions of fact and law relevant to the dispute before it. It thus cannot be the case that the court is restricted in reviewing the order for information. For two reasons, the court hearing the action against the pecuniary administrative penalty must be able to examine the legality of the information order on which the penalty is based:

a. the court is not bound by the administrative order, and

b. the legality of the order is unmistakably a question of law.

The CJEU further reviews whether the review, which the tax authority and the court of the requested state must carry out, is limited to the procedural regularity of the request for information. As the request has the legitimate objective of combating tax evasion and tax avoidance pursued by Directive $2011 / 16$, the court must be capable only of verifying, on the basis of a brief examination, that the information order is based on a request for information that demonstrates a link between, on the one hand, the information requested, the taxpayer concerned and any third party asked to provide information and, on the other, the tax objective pursued. In order to entail a finding of illegality, the deficiency between the request for information and the tax objective must be manifest. This means that the court does not have to confirm the information stated as facts in the request. It may rely on the stated 
facts. A request is only illegal when the tax objective is not manifest. ${ }^{91}$

iv. The fourth question concerns the scope of the concept of 'foreseeably relevant'. Is 'foreseeable relevance' a condition of the validity of the request for information? The concept places a limitation on the obligation to answer a request and constitutes the criterion by reference to which the legality of the information order should be examined by a tribunal for the purposes of Article 47 of the ECFR. The concept is thus a condition that the request must satisfy. ${ }^{92}$

v. The sixth and last question of the referring court asks about disclosure of the competent authority letter. The adversarial principle is a fundamental principle as it permits the exercise of the rights of defence. The link between the requested information and the tax objective pursued by the requesting authority is necessarily developed in the request for information. The initial request for information made by the requesting state must necessarily be brought to the attention of the tribunal hearing the action against the pecuniary penalty, as otherwise it would be unable to carry out the review of legality required by Article 47 ECFR. But the request need not necessarily be brought to the attention of the third party as it cannot be precluded that communication of the request for information to the requested third party might damage the effectiveness of the exchange of information or reduce the prospects of success of the investigation carried out by the requesting authority. Disclosure may consequently be restricted if those reasons are imminent. The restriction on the disclosure should be 'necessary' in order to preserve the fundamental right of another individual or to safeguard an important public interest. Combating tax evasion and tax avoidance constitutes such an important public interest. But the competent authority has to prove to the courts that the interests of the state would be compromised by a precise and full disclosure to the person concerned of the grounds which constitute the basis of the decision at issue. ${ }^{93}$ The minimum information that must be provided to the party shall therefore include at least: (a) the identity of the person under examination or investigation; (b) the tax purpose for which the information is sought.

As can be seen from the above questions referred by the Luxembourg Court of Appeal and the ruling of the CJEU, the amendments imposed by the Global Transparency Forum on Luxembourg, the Netherlands and other countries in the peer review report are currently illegitimate as these measures preclude a party from access to judicial review by a Court. Given the requirement of Article 19 TEU and given the fact that exchange of information for tax purposes is a field cov-

91. Ibid., rec. 89

92. Ibid., rec. 74 .

93. Ibid., rec. 101. ered by Union law, the Member States must provide remedies sufficient to ensure effective legal protection. Therefore, the rule of law is applicable also to the global EOIR Standard as reflected in the DAC.

\subsection{Section Conclusion}

This section on the rights of defence has shown that the Global Forum does not recognise due process rights of the individual. There is a tendency to claim an exceptional status, owing to the important interests of state that are at stake. Slowly, however, the position of the individual subject is becoming recognised as being of legal importance. As the order to provide information has an impact on the subject's legal position, while nonperformance attracts a penalty, an order to provide information should be seen as an administrative act. The subject's evolving position is also reflected in the ruling of the CJEU, who now finds that the legality of an order to provide information should be subject to scrutiny by an independent court.

\section{Legitimacy in Global Governance of Tax}

\subsection{Introduction}

After the Second World War, international policymakers pursued a limited form of internationalisation of their economies with the establishment of the Bretton Woods/GATT institutions, which subjugated international economic integration to the needs and demands of national economic management and democratic politics. ${ }^{94}$ From 1980 onwards, this strategy changed dramatically as global policy began to be driven by an agenda of 'deep' integration, elimination of barriers to trade and capital movements. This 'deep' economic integration cannot be achieved in situations where nation states and democratic policies exert considerable force. ${ }^{95}$ Globalisation of trade and capital requires globalisation of governance, which in itself restrains national sovereignty.

Global governance seeks to integrate the nation-state system with democratic politics and economic and political integration. In the view of Dani Rodrik, however, only two of these three aims are possible. ${ }^{96}$ Accordingly, it will be very difficult to integrate national constitutional rights and global regulations without any democratic foundation. Global governance lacks administrative fairness for the subjects of the regulations. The protection of subjects' interests is subordinated to the efficiency of the procedure. According to Rodrik, a nation-state system and democracy are not compatible with economic integration. He suggests, therefore, to limit the political integration and have more rules on the economic inte-

94. D. Rodrik, 'Feasible Globalizations', NBER Working Paper No. 9129, September 2002 JEL No. FO, 3.

95. Ibid., at 2 .

96. Ibid., at 14 
gration until such time as democratic principles and the rule of law become an integral part of global integration. This questions the legitimacy of global governance, as it currently operates, in the field of tax.

\subsection{Legitimacy}

Global governance in tax brings with it a tension between local and global obligations, with the global standard for administrative cooperation between states being implemented domestically and forced upon local taxpayers. The original inter-state obligation to cooperate with the home state in enforcing bilateral treaty obligations has been converted into a global obligation for taxpayers to assist in suppressing tax evasion worldwide. Taxpayer have thus become instrumental in achieving the goal of global equivalence. The same taxpayers, however, wish to balance their obligations under international law with their global constitutional right to defend themselves against intrusions into their private and family life, and generally to exercise their civic right to respect and dignity, also against interests of other states. The international law enforced upon them can demand compliance only if the rule enforced by that law is itself legitimate. By that I mean that the rule is democratically constituted and enforces an acceptable goal in a fair manner. The suppression of tax evasion is certainly an acceptable goal of great importance for the wellbeing of all citizens of a state. ${ }^{97}$ However, that does not make enforcement of a rule legitimate, even if it is effective. Legitimacy has both an input side (Member States are themselves bearers of legitimacy) and an output side (effective and efficient performance of the task). But effective performance of a task is not sufficient to constitute legitimacy if that performance violates principles of justice as accepted in the rule of law. ${ }^{98}$

What is meant by 'legitimacy'? The term relates to the justification and acceptance of political authority. ${ }^{99}$ According to Bodansky, legitimacy is a third basis of compliance between rational persuasion on the one hand and power on the other. Legitimacy has a normative quality in that it represents justification.

According to Samantha Besson, the key to the authority of international law in pluralist legal orders lies in 'lifting the state veil'100 and focusing on the individual as the ultimate subject of authority in international law. ${ }^{101}$

97. See also EComHR, X (Hardy-Spirlet) v. Belgium, Appl. No. 9804/82, 7 December 1982.

98. See also P. Baker, 'The Rights to Confidentiality and Privacy in an Age of Transparency: A European Perspective', summary of talk delivered at First International Conference on Taxpayers' Rights held in Washington DC in November 2015, <https://taxpayerrightsconference.com/wpcontent/uploads/2015/11/Baker_TPRights_PrivacyandDataProtection_ Nov2015_508.pdf>.

99. D. Bodansky, 'The Concept of Legitimacy in International Law', in R. Wolfrum and V. Röben (eds.), Legitimacy in International Law (Springer, 2008).

100. S. Besson, 'The Authority of International Law - Lifting the State Veil', 31 Sydney Law Review 343-80 (2009). Available at SSRN: <http://ssrn. com/abstract $=1588040>$.

101. Besson, above n. 100

\subsubsection{Kumm's Legitimacy Concept}

Mattias Kumm states that international law has moved away from the domain of foreign affairs to a domain of governance, and is no longer the exclusive territory of states wishing to regulate bilateral affairs. The scope of international law has thus expanded to fields of transnational adjudication and enforcement, and this has consequences for its legitimacy. Emancipation from state control requires new accountability mechanisms. International law is being challenged in domestic settings in the name of democracy and constitutional selfgovernment. ${ }^{102}$ Kumm analyses legitimacy for four distinct principles: (i) the formal principle of international legality; (ii) the jurisdictional principle of subsidiarity; (iii) the procedural principle of adequate participation and accountability, and (iv) the substantive principle of achieving outcomes that are not in violation of fundamental rights and are reasonable. International law is connected to the national constitution in a different way from domestic law and needs, therefore, to improve its decision-making at an international level. This can be done, provided that the above principles are respected. The change from bilateral affairs to governance of globalisation also has an impact on the position of the subject. Governance of global developments affects the subject in that it seeks to govern the conduct of persons beyond the state instead of to govern acts of states. As more and more people are affected by global governance of transnational activities, the question of the legitimacy of the resulting rules comes to the fore.

\subsubsection{Legitimacy of Global Administration of Tax}

The globalisation of governance in international tax with a view to suppressing global tax evasion can be seen as the global administration of tax. The question then is: Do principles of administrative law apply to this global administration? Administrative law is meant to control and restrain the exercising of public power. The current view is that global governance in the area of international tax should be exercised in respect of the rule of law and democracy. Domestic administrative action in the field of international tax should be based on global principles such as equality before the law, democracy and respect for taxpayers' rights. However, the current sources of law for international exchange of information are mainly rules set by non-legislative bodies (the OECD and Global Transparency Forum as government networks). Domestic and international elements have become interwoven in the process of regulation, whereby domestic constitutional rights are being exchanged for universality of the rule. In other words, the universality of an efficient system for exchanging information has gained priority over constitutionally protected rights of defence. The better way would have been to reenforce protection of legal interests and to include civic rights in the global rule, irrespective of the plurality of national constitutional rights or the absence of such

102. M. Kumm, 'The Legitimacy of International Law: A Constitutionalist Framework of Analysis', 15(5) EJIL (2004). 
rights. In order to overcome the political trilemma of Rodrik, global governance should be amended to incorporate relevant elements of nation-state constitutional rights for the individual. These rights can be found in global administrative law principles such as transparency, consultation, participation, rationality and legality, effective review of rules and decisions.

International law basically has a state-oriented character. Rather, however, than expanding horizontally to embrace new states, it has extended itself vertically to include individuals, groups and international organisations within its scope. ${ }^{103}$ The end of the Second World War saw the recognition of individual responsibility under international law without and beyond the state, while the growing interest in human rights has contributed to the increasing role of the individual in international law. Emphasis on the dignity of man provides an ethical basis for international law.

\subsection{Section Conclusion}

In order for a rule to be legitimate, any weak legitimacy in the constitution of the rule must be compensated by strong procedural legitimacy in its application. As explained earlier, the democratic legitimacy of the Global Transparency Forum is non-existent. Therefore, any legitimacy the Global Transparency Forum may have relates to the efficacy of the output and must be based on respect for the rule of law.

The previous section concluded that observance of the rule of law in the form of procedural fairness is crucial to the legitimacy of the EOIR Standard. As we have seen, however, that Standard does not provide for any procedural fairness in the EOI process. For Ana Dourado, this conclusion constituted sufficient grounds for stating that the EOIR Standard cannot be accepted as a global standard. To become acceptable on a global level, it needs to be strengthened by the addition of procedural fairness, both for the taxpayer subject to an investigation and for the person ordered to cooperate in the information collection process. As P. Baker puts it, 'Nothing authorizes tax administrations to ignore the rights of taxpayers.' The provisions in the Terms of Reference on respect for rights of information holders (B.2) and data protection in the exchange process (C.4) are designed to be subordinate to an efficient exchange process. For this reason, the Global Transparency Forum has forced some states to renounce notification and to restrict access to justice for those wishing to challenge the legality of the exchange of information, as well as to impose a prohibition on disclosing competent authority letters, as evidenced by the examples given in the opening section. The sources for the EOIR Standard and the resulting Terms of Reference do not give the Global Transparency Forum a mandate to include limitations on the rights of defence in the Terms of Reference. Indeed, the Global Transparency Forum has no

103. For a brief summary of the development of international law over the centuries and decades, see M.N. Shaw, International Law, 6th ed. (Cambridge University Press, 2008), 43-68. executive authority to impose the above restrictions on states that have made commitments to transparency.

The amendments made to local procedural rules as a result of the Global Transparency Forum's work cannot be challenged under local law. The only remedy, therefore, must be sought in international customary law that supersedes domestic law and in international and supranational law. Under the ECHR, persons concerned have standing against the acting state for any infringement of their human rights, as guaranteed by the Article 8 with respect to natural persons and, in some instances, also legal persons. Under the ECFR, persons concerned have a right to respect for private life (Article 7) and to data protection (Article 8). This protective framework of constitutional defence rights takes priority over national law. The ECFR comes into play if primary EU law (TEU, TFEU or ECFR) or secondary law (DAC 1 and DPD) 'touch' upon national law (Article 51(1) CFR).

\section{Conclusion}

The EOIR Standard for tax purposes, as developed by the OECD and implemented through the peer review procedures of the Global Transparency Forum, is not legitimate because it denies the person concerned recourse to the defence rights provided by the rule of law. This conflict between efficiency and effectiveness in the application of basic personal rights for the person concerned can only be resolved by the law. In adjudicating conflicts of this nature, the courts have to take into consideration that the rule forced upon the persons concerned lacks legitimacy. The Standard should therefore be revised to include rights of defence for the persons concerned in the form of a right to be notified of any intended exchange of information (now acknowledged in M.N. and others v. San Marino), a right to have the legality of the order reviewed by an independent court (now acknowledged in Berlioz) and a right to data protection (now acknowledged in Schrems v. Data Protection Commissioner). These rights must apply to all persons concerned, whether they are taxpayers or third-party informants. The level of protection afforded to the taxpayer should be at the level of the requested state with regard to the collection and exchange of information and at the level of the requesting state with regard to the use of data as evidence for the assessment.

I regard the Data Protection Directive and forthcoming General Data Protection Regulation (GDPR) as containing important procedural safeguards against the improper use of exchanged data. ${ }^{104}$ Tax data may flow freely within the EU, but a data flow outside the EU is restricted. In my opinion, this will lead to a proliferation

104. Regulation (EU) $2016 / 679$ of the European Parliament and of the Council of 27 April 2016 on the protection of natural persons with regard to the processing of personal data and on the free movement of such data, and repealing Directive 95/46/EC (General Data Protection Regulation) (Regulation (EU) 2016/679) OJ L 119, 4 May 2016, 1-88. 
of the EU's data protection rules on a global scale. Another important element of the legal protection shield in Europe is that information obtained through administrative assistance must be reviewed for compliance with human rights standards, as reflected in the ECHR, in the country where that information is collected. ${ }^{105}$

In balancing the rights of the person concerned to privacy and data protection against important interests of both the requested and the requesting states, there must be a judicial review of the requested state's adherence to human rights concepts of the requesting state. The protection shield's equivalence in both states must be a condition for the use of the received information in the requesting state. This will also mean a proliferation of European human rights norms in global exchange of information procedures. The proportionality and necessity arguments should restrict the volume of exchanges, while the legitimacy argument should imply a thinner version of the international tax governance rules, including full recourse to the rule of law.

The Terms of Reference for peer review by the Global Transparency Forum currently take no account of the rights of the persons involved. ${ }^{106}$ This lack of legal protection of such persons violates the rule of law in respect of due process, privacy protection and data protection. As such, I support Ana Dourado's conclusion that the EOIR Standard lacks legitimacy.

105. For an example of such a review, see ECtHR 7 July 2015, M.N. and others v. San Marino, Appl. No. 28005/12, where the court imposed a notification obligation on San Marino prior to the exchange of information in order to protect the right to a judicial review of the order's legality.

106. With regard to the preservation of confidentiality in the exchange process, recent OECD reports (BEPS Action 5 on Harmful Tax Practices: Transparency Framework - Peer review documents, OECD, 2017, at 13 and BEPS Action 13 on Country-by-Country Reporting - Peer review documents, OECD 2017, 15-16) have included more extensive terms of reference elements than those of the Global Transparency Forum, especially in respect of the domestic enforcement of the confidentiality rules. Nevertheless, those elements are still insufficient to comply with the stricter EU data protection rules set out in the GDPR. 